\title{
Rigidity of the affected femurs with systems of surgical treatment
}

\author{
N. Shidlovskiy ${ }^{1} \bullet$ M. Dyman ${ }^{1} \bullet$ A. Ilnitsky ${ }^{2} \bullet$ V.Shytikov $^{1}$ \\ 1 - Igor Sikorsky Kyiv Polytechnic Institute, Kyiv, Ukraine; \\ 2 - SI «Institute of Traumatology and Orthopedics NAMS Ukraine», Kyiv, Ukraine
}

\begin{abstract}
Purpose. Subject matter of the present paper is to investigate the characteristics of rigidity and reliability of fixing of pathological changes at metastatic defeat are investigated in real, including cyclic, the modes of influence of external loadings. Design/methodology/approach. During experiment was used of extremities without pathology of a bone tissue and with a tumor on a bone tissue. Fixing of bone fragments (osteosynthesis) has been executed by means of the device of external fixing of A. Kostiuk and by means of reinforcing of a metal osteosynthesis by system with application of a extramedullar plate and bone cement. Tests were carried out, transferring freight on the fixed femur fragment change diversely. Ways of loadings: compression, a bend and rotation and cyclically variable freights which model human weight.

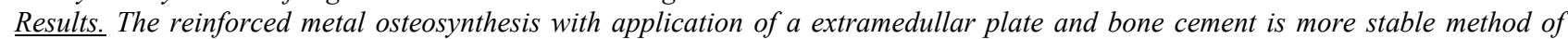
fixing in comparison with rod devices of external fixing like AVF-K. Fixing of a change in the way of a metal osteosynthesis significantly interferes with development of deformations at action of cyclic loadings. Is the most dangerous from the point of view of physiological reliability for both studied systems of an osteosynthesis bending and rotational loadings.

Originality/cost. Results are important for medicine and can improve treatment.
\end{abstract}

Keywords: osteosynthesis; metastatic bone tumor; reinforced osteosynthesis; transosseus extrafocal osteosynthesis; fragments fixation stiffness; power fixation of fractures; fracture fixation stability; extramedullar plate; bone cement; thigh-bone

Introduction. Today, surgical treatment of patients with metastases of the long bones is one of the key method in this pathology [1-3]. In the case of metastatic lesions of long bones surgical procedure aimed to improve the quality of life of these patients (reduction of pain, stabilization of the affected bone segment), the ability to restore the function of the affected limb in the shortest possible time, provide local tumor control and continuation of specific treatment [4-6].

Apparatus' elements of external fixation rod devices (EFRD) may be placed at a sufficient distance from the lesion and patients during radiotherapy can move independently and meet their most basic needs [7-9].

Means of osteosynthesis (MoO) must be sufficiently rigid and stable during long-term treatment, which may be accompanied by compression, bending and rotary loads of bones.

Analytical determination of mutual displacement of fragments of bones under stress is a hard challenge, due to the specific mechanical properties of bone stock (visco-elastic effects, anisotropy, heterogeneity elastic modulus, etc.) and complex configuration of the long bones in the metastatic lesions. Experimental research of rigidity and stability of fixation on the medicine in situ real types and levels of stress today provides the most reliable results.

From here on besides of the total deformation of the whole system "bone - retaining means" bone parts' mutual offset under physiological stress also will be considered. As the characteristics of stability the degree of change of displacement with time under the influence of long-term cyclic loading will be considered.

Problem formulation. To further improve the "means fixing - struck bone" system it is necessary to determine the characteristics of rigidity fixation of pathological fractures on the background of metastatic lesions using different types of osteosynthesis, that fixes a pathological fracture of the femoral shaft $(F)$ in the real, including the cyclic mode of action external loads.

Objects and methods of research. Abstract deformation processes in single and cyclic loading of such objects:

- Undamaged femurs (F-U),

- Femur fractures that are fixed with the "external fixation rod device" of A. Kostiuk [10] (hereinafter referred to F-A);

- Femur fractures, reinforced by osteosynthesis system with extramedullary plate and bone cement (the F-C). 
In our experiments we used anatomical limbs of people's corpses who died from injuries and diseases not associated with disorders of the musculoskeletal system.

Intact femurs in the amount of 3 pieces. were tested according to the program shown below. Then transverse osteotomy was performed to simulate a simple transverse fracture. After this, fixation was performed with consistent use of EFRD device and metal osteosynthesis.

To eliminate extraneous deformations between samples and the elements of the test equipment the bone epiphyses were fixed with method, described in $[11,12]$. The support head (Figure 1) in the form of parallelepipeds were pre-poured from special plastic - acrylic composition groups of cold fast approval.

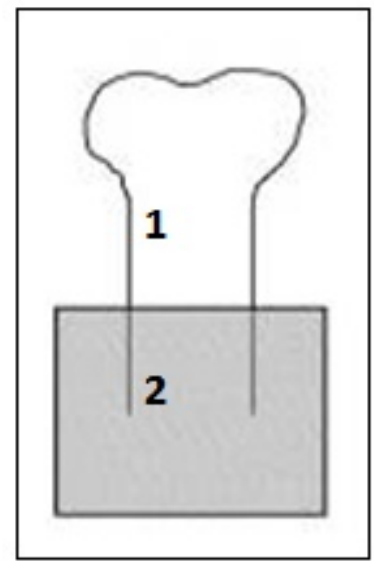

$a$

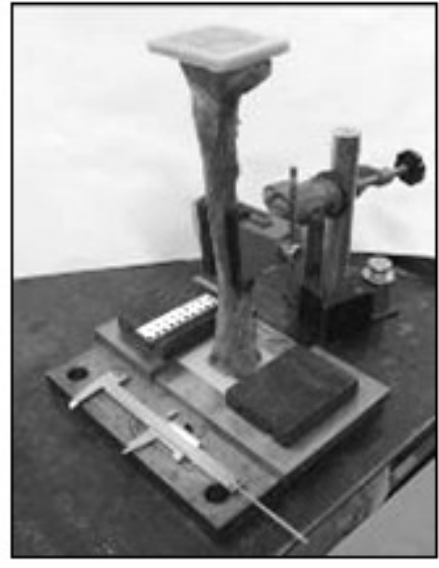

$b$

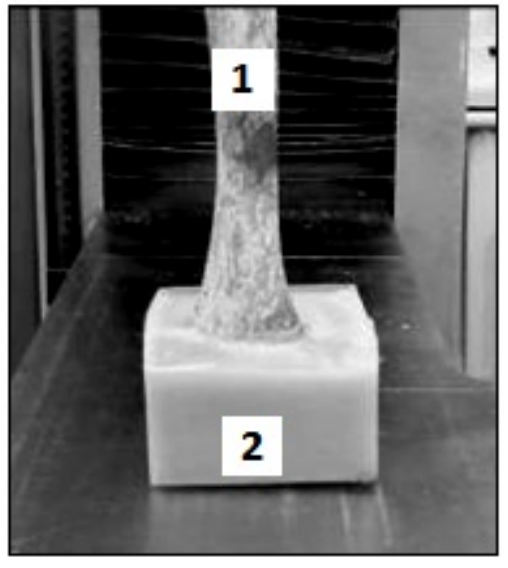

Fig. 1. Scheme of plastic type base head (a) Bone fixation in the production of props(b) a bone with complete prop (c); 1 - Bone 2 - bearing head introduced:

Geometric characteristics of medicine, prepared for trials are shown in Table. 1. The following notations

$\mathrm{H}_{1}$ - distances from the extreme point at head joints to fracture (Figure 2a). 2a).

$\mathrm{H}_{2}$ and $\mathrm{H}_{3}$-distances from the top point of the trochanter major to fracture and to fixation, respectively (Figure

D - diameter of the head $F$ (Figure $2 \mathrm{a}$ ).

$\mathrm{L}_{\mathrm{CT}}$ - distances from the point of load of compression applications $\mathrm{P}_{\mathrm{X}}$ to the longitudinal wasps bone (Figure $2 \mathrm{~b}$ ).

$\mathrm{L}_{3 \Gamma}$ - distances from the point of load of bending applications $\mathrm{P}_{\mathrm{Y}}$ to fracture (Figure 2c).

$\mathrm{L}_{\mathrm{KP}}$ and $\mathrm{R}_{\mathrm{KP}}$ - distances from the point of load of rotary applications $\mathrm{P}_{\mathrm{Z}}$ to fracture and bone for longitudinal wasps, respectively (Figure 2 g.).

Table 1

Geometric characteristics (mm) femurs and Location of Point Range of load applications in the trials (meaning in Text and at Fig. 2a-2d)

\begin{tabular}{|c|c|c|c|c|c|c|c|}
\hline$H_{1}$ & $H_{2}$ & $H_{3}$ & $D$ & $L_{C T}$ & $L_{3 \Gamma}$ & $L_{K P}$ & $R_{K P}$ \\
\hline $130 \pm 2$ & $118 \pm 2$ & $215 \pm 3$ & $45.5 \pm 1$ & $40 \pm 1$ & $87 \pm 2$ & $95 \pm 2$ & $52 \pm 1$ \\
\hline
\end{tabular}
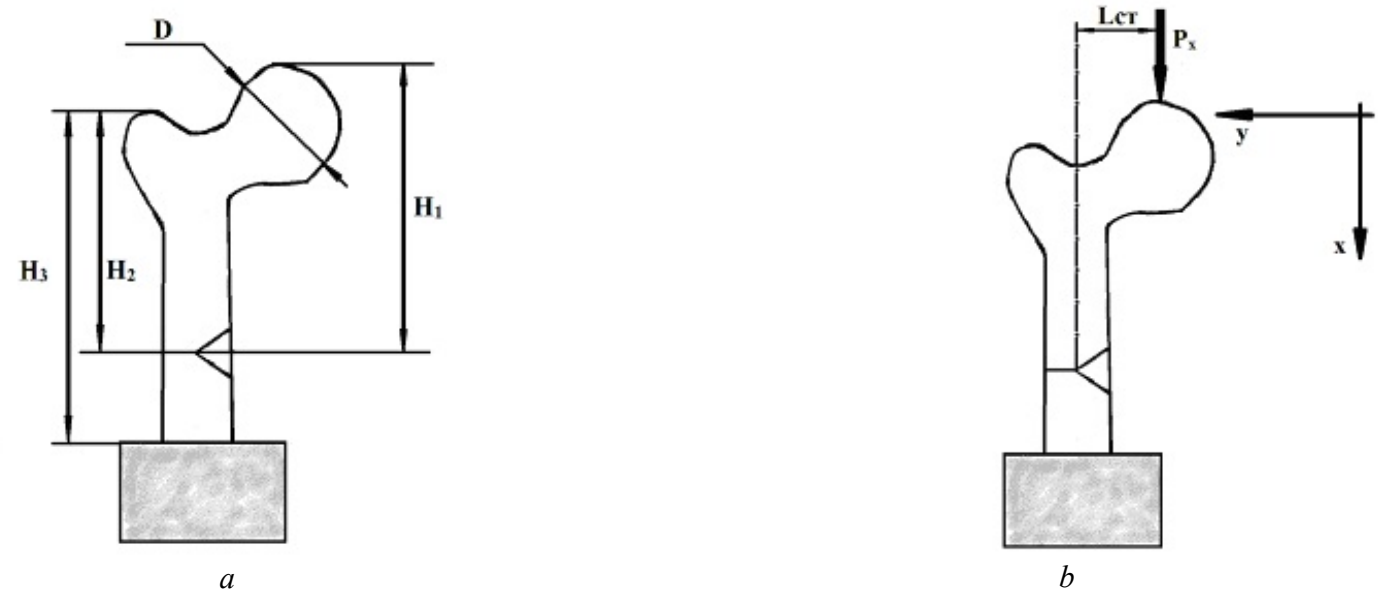


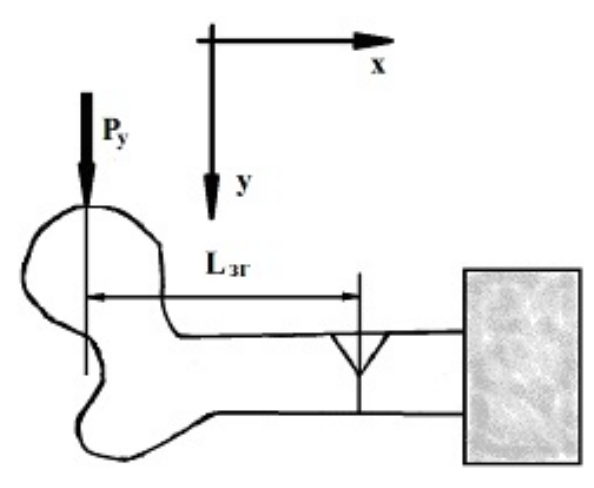

c

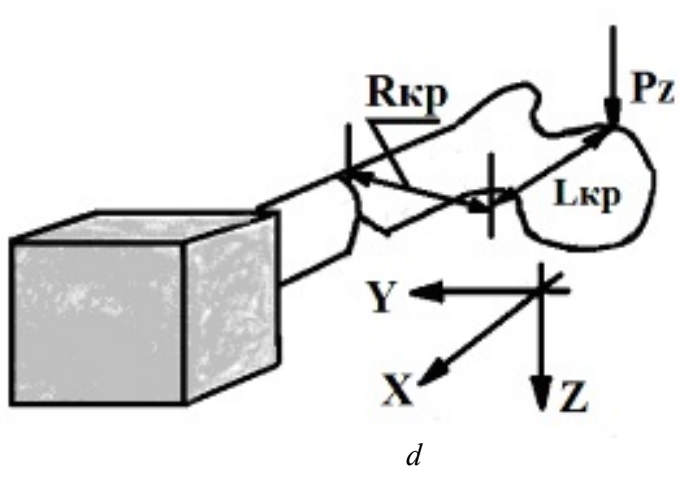

Fig. 2. Geometric characteristics of a femur (a) and location of the points of application of compressive loads with compression (b), bending (a) and torsional (d)

Research Methodology. The load of "F - MoO" was conducted on a universal testing machine [11, 12] (Fig. 3). Pressure force was measured with the help of dynamometer testing machine with an accuracy of $\pm 0.1 \mathrm{~N}$. Accuracy of moving mobile terminals was $\pm 0.01 \mathrm{~mm}$ at a velocity of active terminals $5 \mathrm{~mm} / \mathrm{min}$ (compression and rotation) and 50 $\mathrm{mm} / \mathrm{min}$ (bend). These speeds allow one load for 10 - 20 seconds.

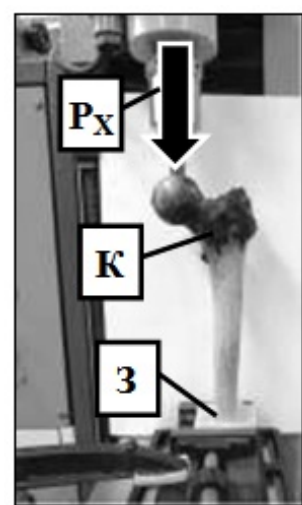

$a$

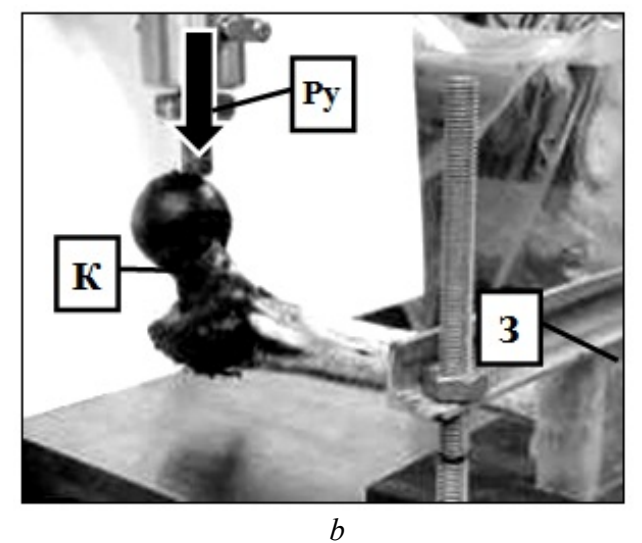

$b$

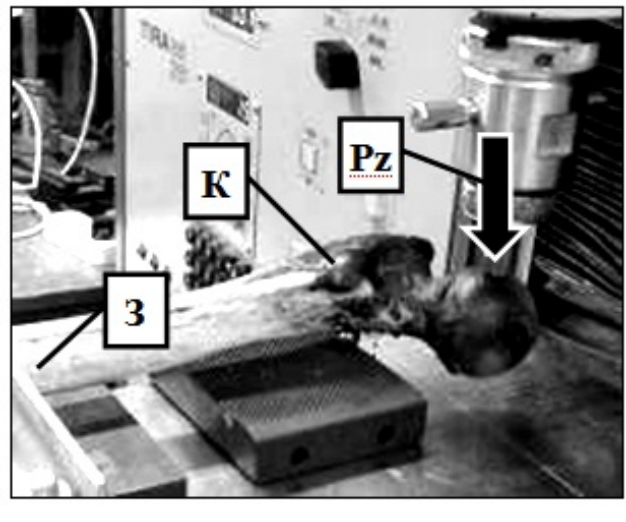

$c$

Fig. 3. Samples of intact femur on the desktop of compression testing machine (s), bending (b) and torsional (c): $\mathrm{K}$ - bone; 3 - consolidation; Arrow - direction and point of application of load

Test for axial compression loads. Supporting head pattern was nipped in a clamp that was placed at the desktop of a testing machine and was loaded with compressive loads (Fig. 3a). Desktop shifted vertically upwards so that the rod of dynamometer test installation was touching the free end of the bone. The load was applied to the top of the head joint.

It should be noted that with the load that is applied this way an additional bending moment appears $M=P_{X} \cdot L_{C T}$ so more accurately the load has to be called "compression of the bend." However, the force's application to the top of $\mathrm{P}_{\mathrm{X}}$ joint head of emerging with force displacement relative to the longitudinal axis of the femur meets the real physiological load and is justified.

Compressive force was measured with dynamometer machine, and the overall deformation (movement of the point of application loads or vertical movement of the Desktop) - a device for measuring displacement that is mounted to a test machine. The method of measuring the relative displacement of the bone fragments as described below

Test for bending loads. Supporting head with the console-located bone was fixed on the desktop using the hard clamps that were installed on the moving traverse test setup (Fig. 3b). Loading $\mathrm{P}_{\mathrm{Y}}$ is applied in the frontal plane of the bone.

Test for torsional loads. Sample from the first end was rigidly fixed to the terminals installed on the desktop testing machine so that the bone sagittal plane was perpendicular to load direction (Fig. 3c). Torque $M_{K}=P_{Z} \cdot R_{K P}$ was created using a pressure of rod dynamometer at the round surface of the head joint. To relieve the bending load at the free end of the bone lining steel ball with a diameter of $6 \mathrm{~mm}$, that relied on the desktop.

The above methods were tested intact bones F-U (Fig. 3) System F-A and F-C (Fig. 4). 


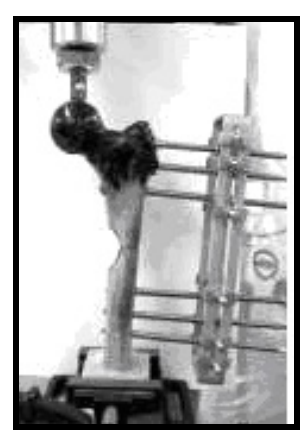

$a$

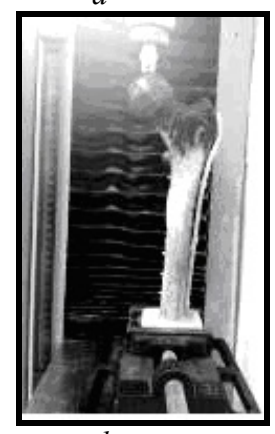

$d$
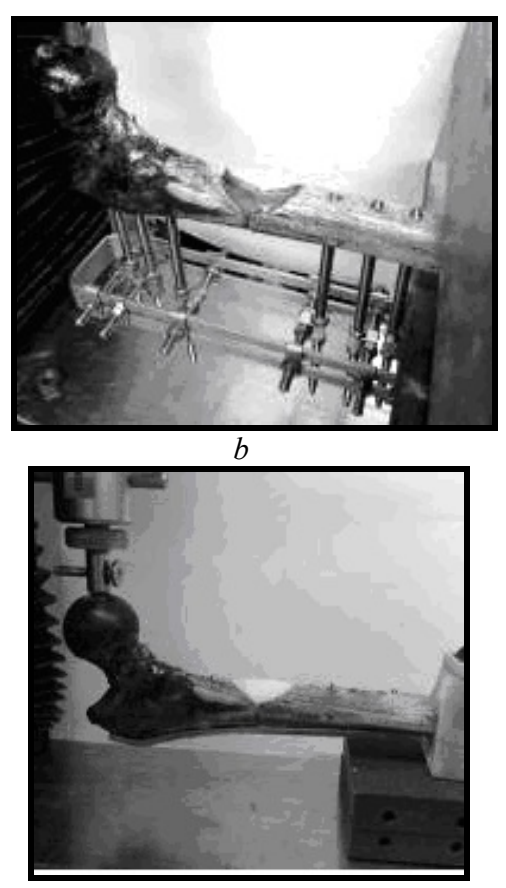

$e$
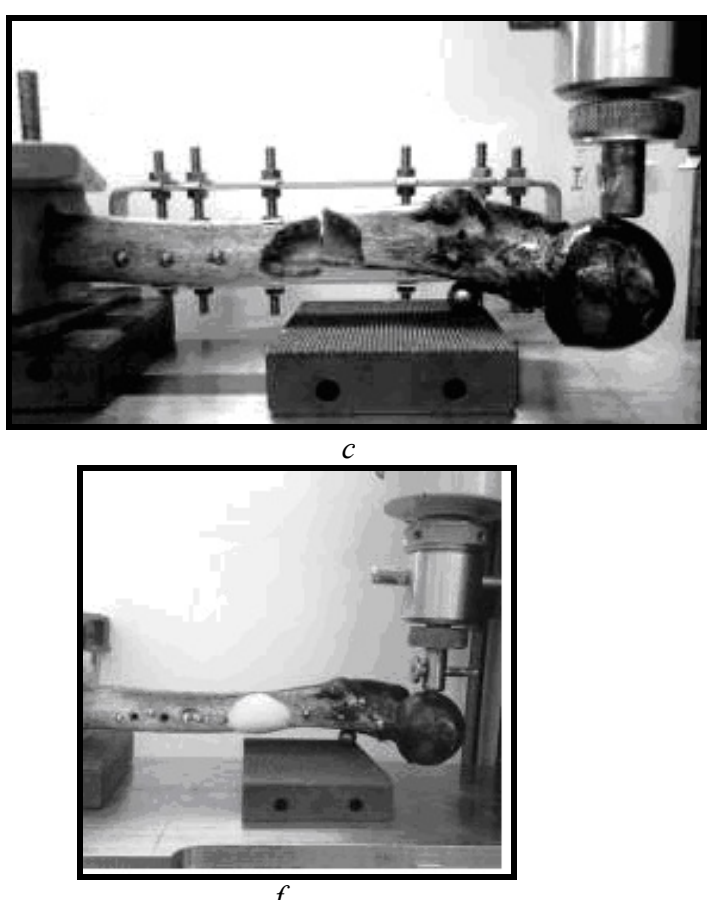

$f$

Fig. 4 - Test femur fracture, fixed with apparatus EFRD (a, b, c), and a system of metal osteosynthesis using extramedullary plate and bone cement (d, e, f) compression (a, d) bending (b, d) and torsion (a, e)

To register displacements of biological products, including of reference (reference) point used digital photography and filming [12]. Block diagram of the action sequences in the tests shown in Fig. 5. Pre-load in the tests was $50 \mathrm{~N}$. After the experiment - received information was recorded in a diagram of deformation in coordinates $\mathrm{P}$ absolute deformation $\Delta$

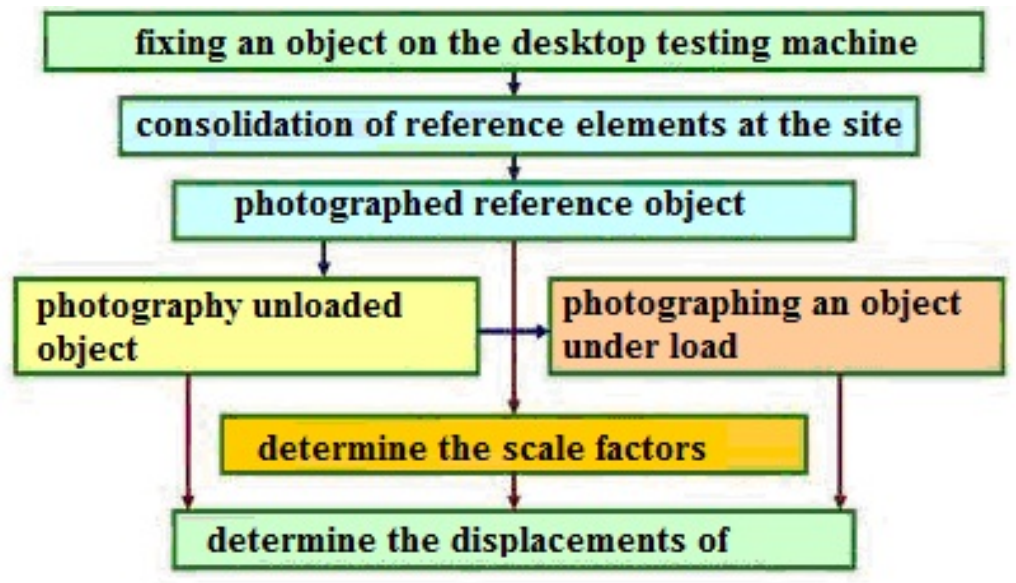

Fig. 5. The sequence of displacements

Test results and analysis.

One-time short-term loads. According to the above method the diagrams of deformation under compression, bending and torsion specimens F-U, F-A and F-C were constructed. Typical deformation diagrams shown in Fig. 6.
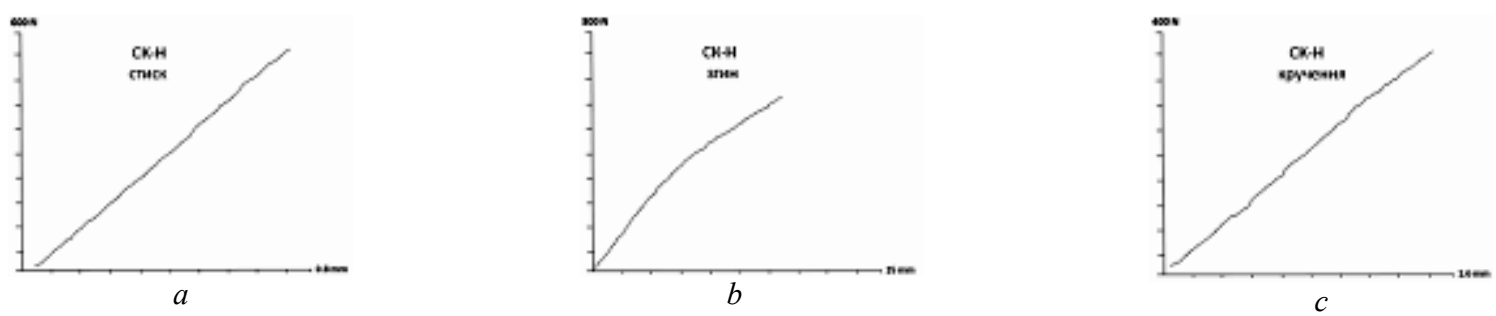

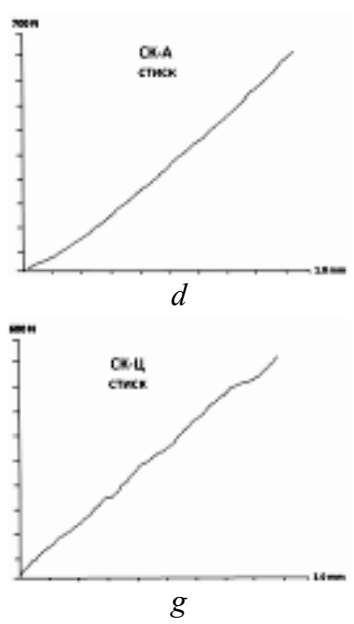
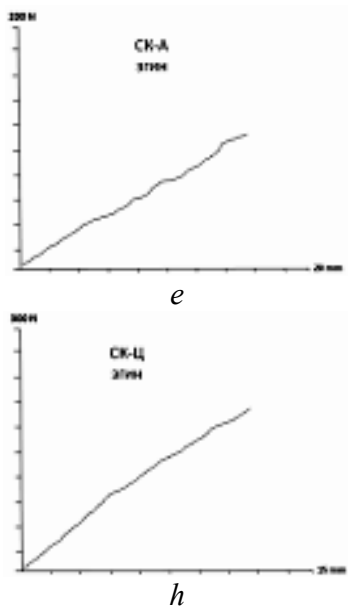

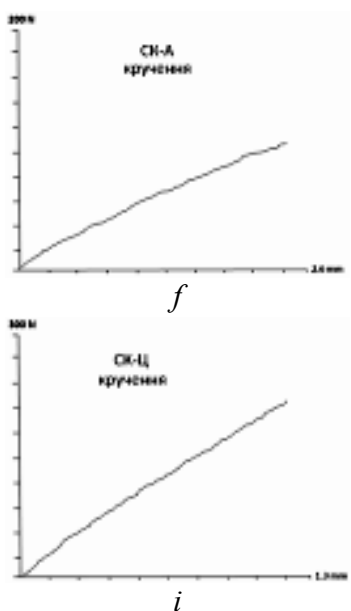

Fig. 6. Diagrams of figure deformations F-U (a, b, c), F-A (d, e, f) and F-C (F, s) compression (a, h, i), the bend (B, e) and tensional $(\mathrm{c}, \mathrm{e}, \mathrm{s})$

From now on we will conduct an analysis of the test results, in terms of hardness values as a ratio of applied load to experiment with the emerging movement of a point of load (Fig. 2): $\mathrm{C}_{\mathrm{X}}=\mathrm{P}_{\mathrm{X}} / \Delta_{\mathrm{X}}, \mathrm{C}_{\mathrm{Y}}=\mathrm{P}_{\mathrm{Y}} / \Delta_{\mathrm{Y}}, \mathrm{C}_{\mathrm{Z}}=\mathrm{P}_{\mathrm{Z}} / \Delta_{\mathrm{Z}}$, де $\mathrm{P}_{\mathrm{X}}, \mathrm{P}_{\mathrm{Y}}, \mathrm{P}_{\mathrm{Z}}, \Delta_{\mathrm{X}}, \Delta_{\mathrm{Y}}, \Delta_{\mathrm{Z}}$ - load and displacement during compression, bending and torsion, respectively.

Table. 2 summarizes the test results of intact femur (F-U) samples of simulated fractures that were fixed with apparatus of A. Kostiuk (F-A) and reinforced with "extramedullary plate - the bone cement" system (F-C) compression, bending and torsion. Confidence intervals are calculated with probability $\mathrm{p}=0.95$ for $\mathrm{N}=3$.

Table 2

Average data test medicine and the spread of results

\begin{tabular}{|c|c|c|c|}
\hline \multirow{2}{*}{ Kind trial } & \multicolumn{3}{|c|}{ Tightening systems $\mathbf{C}_{\mathbf{J}}=\mathbf{P}_{\mathbf{J}} / \Delta_{\mathbf{J}}(\mathbf{H} / \mathbf{M M})$} \\
\cline { 2 - 4 } & $\mathbf{F}-\mathbf{U}$ & $\mathbf{F}-\mathbf{A}$ & $\mathbf{F}-\mathbf{C}$ \\
\hline \multirow{2}{*}{$\begin{array}{c}\text { Squeeze } \\
\text { (compression) }\end{array}$} & $668.9 \pm 20.1$ & $400.7 \pm 32.3$ & $* 23.1 \pm 15.5$ \\
\cline { 2 - 4 } & & $* 291.6 \pm 14.9$ & $17.3 \pm 0.61$ \\
\hline \multirow{2}{*}{ Bending } & $30.6 \pm 0.65$ & $9.64 \pm 0.48$ & $* 15.9 \pm 0.95$ \\
\cline { 2 - 4 } & & $* 8.85 \pm 0.37$ & $168.4 \pm 5.27$ \\
\hline $\begin{array}{c}\text { Torsion } \\
\text { (rotation) }\end{array}$ & $261.3 \pm 6.5$ & $55.8 \pm 2.23$ & $* 170.0 \pm 4.13$ \\
\hline
\end{tabular}

Note: asterisk observed the results of tests conducted after exposure to cyclic loadings

Table. 3 shows the data on changes of stiffnesses due to fracture and its fixation in two ways compared to the intact femur. These data is presented as the ratio of stiffnesses $\psi_{K}=C^{\Pi} / C^{H}$, where $C^{H}$ - femur tightening intact, $C^{\Pi}$ simulated stiffness of bone fracture and fix the system.

Table 3

- Indicators of stiffness of devices RCF-K and fixes with metal cement

\begin{tabular}{|c|c|c|c|c|}
\hline \multirow[t]{2}{*}{ Kind trial } & \multicolumn{2}{|c|}{$\begin{array}{c}\text { Comparison with intact bone } \\
\qquad \psi_{\kappa}=C^{\Pi} / C^{H}\end{array}$} & \multicolumn{2}{|c|}{$\begin{array}{l}\text { The impact of the cyclical } \\
\text { load } \\
\qquad \psi_{\amalg}=C^{\amalg} / C^{\Pi}\end{array}$} \\
\hline & F-A & F-C & F-A & F-C \\
\hline Squeeze (compression) & 0.63 & 0.93 & 0.73 & 0.96 \\
\hline Bending & 0.31 & 0.57 & 0.91 & 0.92 \\
\hline Torsion (rotation) & 0.21 & 0.64 & 0.76 & 1.00 \\
\hline
\end{tabular}


Impact on the type of fixation rigidity connection

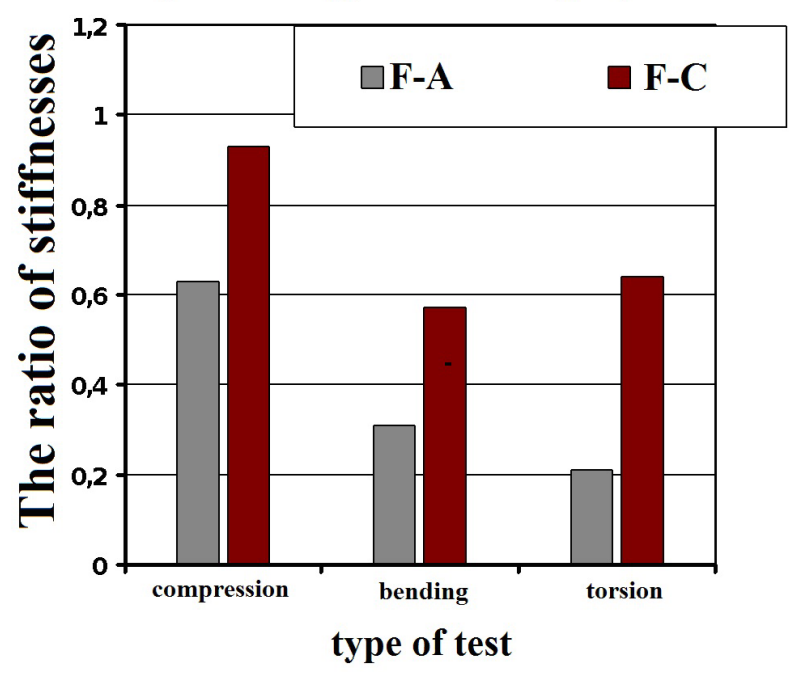

Fig. 7. The ratio of the rigidity of femur fractures, osteosynthesis fixed systems SC-A and SC-C hardness to the intact femur
For clarity these data is shown in Fig. 7 as comparative charts.

The comparison of results shows a greater degree of rigidity storage metal osteosynthesis fixation using plate and extramedullary bone cement (F-C) compared with intact femur.

With the application of F-A the stiffness compared to intact bone is reduced by $37 \%$ (compression) to $79 \%$ (twisting), then fix the F-C rigidity almost kept (falling less than $7 \%$ compression) or reduced by $36 \%$ (torsion ) to $43 \%$ (bend). For both types of fixation the largest rigidity decline observed in the action of bending and torsional loads.

Long-term cyclic loading. The change of stiffness of osteosynthesis systems under cyclic loads that simulated the effect of compounds on bone or physical distance factor therapeutic exercises has been investigated. Such Cyclic loading model was run [1113]: deformation of the sample at a speed of $5 \mathrm{~mm} /$ min to the emergence of $\mathrm{P}_{\mathrm{MAX}}$ force; exposure of the sample with the load during $1 \mathrm{c}$; unloading the sample at the same rate to $\mathrm{P}_{\mathrm{MIN}}$; exposure of the sample with the load during 1s. After this the cycle repeated. The maximum number of cycles for each sample was equal to 50 .

Table. 3 shows the parameters of hardness change after exposure to cyclic loads (load $\mathrm{P}_{\text {MAX }}=300 \mathrm{~N}$ compressive, flexural $100 \mathrm{~N}$ and $50 \mathrm{~N}$ torsional). Changing the properties of a system characterized by the ratio of stiffnesses

$$
\psi_{ц}=\mathrm{C}^{\amalg} / \mathrm{C}^{\Pi},
$$

where $C^{\Pi}$ - simulated stiffness of bone fracture fixation system and to cyclic loading, $C^{Ц}$ - after cyclic testing.

Comparative diagrams that illustrate the data shown in Fig. 8.
Effect of cyclic loads on stiffness connection

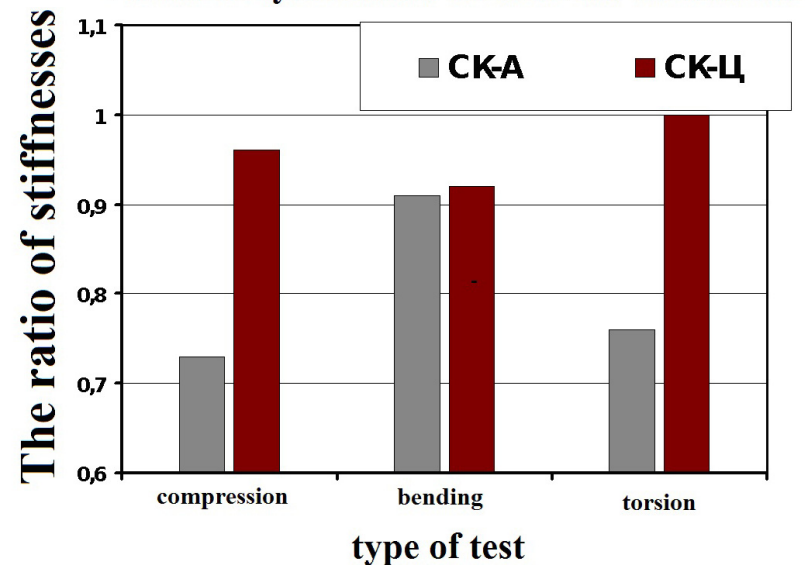

Fig. 8. The ratio of stiffnesses osteosynthesis action after cyclic loading to the stiffness in the initial state (to cyclic loading)
We should note the high rigidity storage systems, metal osteosynthesis fracture fixation F-C in the action of cyclic loads. The action of torsional rigidity is preserved under the influence of compression and bending in this system falling hardness does not exceed $4-8 \%$. At the same time, the system F-A shows significantly less stability, rigidity fall under cyclic loads at $24-27 \%$ compression and torsion. During the bending reduce the stiffness in that system did not exceed $9 \%$.

\section{Conclusions}

1. Usage of the proposed method and indicators of operating reliability can significantly simplify and speed up the assessment of the quality of fixation of pathological fractures of metastatic tumors of the long bones.

2. Fixation of pathological fractures of the femur diaphysis against the backdrop of metastatic lesions, explored with ways of osteosynthesis reduces deformation development at the site of a pathological fracture under the action of compressive loads and

substantially increases the system's stability.

3. Reinforced metal osteosynthesis using extramedullary plate and bone cement is more stable fixation method compared to the rod apparatus of external fixation type RCF-K. Fracture fixation metal osteosynthesis method substantially prevents deformation of the action of cyclic loads.

4. The most dangerous in terms of functional reliability for both systems studied osteosynthesis is bending and rotational load. 


\title{
Жорсткість уражених стегнових кісток із системами хірургічного лікування
}

\author{
М.С. Шидловський, М.М. Димань, О.В. Ільніцький, В.С. Шитіков
}

Анотація. Досліджено характеристики жорсткості та надійності фіксації патологічних переломів при метастатичному ураженні за допомогою апарата зовнішньої фіксаиї А. Костюка та за допомогою армування системою металоостеосинтезу із застосуванням накісткової пластини та кісткового цементу у реальних, включаючи циклічні, режимах дії зовнішніх навантажень. Вибір оптимального методу хірургічного лікування при метастатичному ураженні кістки зумовлений локалізацією $і$ протяжністю процесу в кістиі, наявністю або відсутністю м'якотканинного компонента пухлини, наявністю і давністю патологічного перелому, чутливістю пухлини до спеиифічної терапії.

Ключові слова: остеосинтез, метастатична пухлина кістки, армований остеосинтез, через кістковий, поза-вогнищевий остеосинтез, жорсткість фіксаиії переломів, міџність фіксації переломів, стабільність фіксації переломів, накісткова пластина, кістковий иемент, стегнова кістка.

\section{Жесткость пораженных бедренных костей с системами хирургического лечения}

\author{
Н.С. Шидловский, М.М. Дымань, А.В. Ильницкий, В.С. Шитиков
}

\begin{abstract}
Аннотация. В статье исследованы характеристики жесткости и надежности фиксации патологических переломов при метастатическом поражении с помощью аппарата внешней фиксации А. Костюка и с помощью армирования системой металоостеосинтеза с применением накостной пластины и костного цемента в реальных, включая ииклические, режимах воздействия внешних нагрузок. Выбор оптимального метода хирургического лечения при метастатическом поражении кости предопределен локализацией и протяженностью процесса в кости, наличием или отсутствием мягкотканевого компонента опухоли, наличием и давностью патологического перелома, чувствительностью опухоли к специфической терапии.
\end{abstract}

Ключевые слова: остеосинтез, метастатическая опухоль кости, армированный остеосинтез, черезкостный, внеочаговый остеосинтез, жесткость фиксации переломов, прочность фиксации переломов, стабильность фиксации переломов, накостная пластина, костный цемент, бедренная кость.

\section{References}

1. Bur'yanov, O.A. (2011), "Nash dosvid likuvannya hvorih z metastatichnim urazhennyam kistok", Travma, 12 (2) pp. $112-4$.

2. Sim, F.H. (1992), "Metastatic bone disease of the pelvic and femur", Instr Course Lect, 41, pp. 317-27.

3. Futani, H., Kamae, S. and Atsui, K. (2002), "Successful limb salvage of pathological fracture of the distal tibia caused by cancer metastasis", Orthop Sci, 7 (2), pp. 262-6.

4. Teplyakov, V.V., Karpenko, V.Yu. and Valieva, A.K. (2005), "Hirurgicheskoe lechenie patologicheskih perelomov dlinnyih trubchatyih kostey pri metastaticheskom porazhenii”, Vopr.onkol, 51 (3), pp. 377-81.

5. Tihilov, R.M., Grigorev, P.V. and Zasulskiy, F.Yu. (2009), "Hirurgicheskoe lechenie bolnyih s metastaticheskimi porazheniyami dlinnyih kostey", Materialyi Vserossiyskoy konferentsii s mezhdunarodnyim uchastiem "Endoprotezirovanie krupnyih sustavov", Moskow, 21-22 aprelya.

6. Bickels, J., Dadia, S. and Lidar, Z. (2009), "Surgical management of metastatic bone disease", J Bone Joint Surg Am, 91 (6), pp. 1503-16.

7. Spencer, S.J. (2001), "Locked intramedullary nailing of symptomatic metastases in the humerus", J Bone Joint Surg Br, 92-B (1), pp. $142-5$.

8. Wedin, R. (2005), "Surgical treatment of skeletal metastatic lesions of the proximal femur: endoprosthesis or reconstruction nail", J Bone Joint Surg Br, 87-B, pp. 1653-7.

9. Fleisch, H. (2000), Bisphosphonates in bone disease, From the laboratory to the patient, Fourth Ed. Academic Press, San Diego-London, pp. 68-87.

10. Karachalios, T., Atkins, R.M. and Sarangi, P.P. (1993), "Reconstruction nailing for pathologi-cal subtrochanteric fractures with coexisting femoral shaft metastases", J Bone Joint Surg Br; 75-B, pp. 119-22.

11. Kostyuk, A.N. (2015), Posibnik z metodiki osteosintezu aparatami zovnishnoyi fiksatsiyi AZF-K, TOV "Lazurit-poligraf", Kyiv, Ukraine.

12. Shidlovskiy, N.S. (2011), Metodyi issledovaniya deformatsionnoy nadezhnosti sistem osteosinteza konechnostey cheloveka, Biomedichna Inzheneriya, Kyiv, no 1, pp. 24-31.

13. Shidlovskiy, N.S., Laksha, A.M. and Shpak, D.E. (2011), Naturnyie ispyitaniya sistem "bolshebertsovaya kost s perelomom - sterzhnevoy apparat fiksatsii", Visnik Natsionalnogo tehnichnogo universitetu Ukrayini "Kiyivskiy politehnichniy institut", Seriya Mashinobuduvannya, Kyiv, no 61 vol. 2, pp. $134-140$.

14. Shidlovskiy, N.S., Laksha, A.M. and Dyman, M.M. (2014), Osobennosti vyibora rezhimov biomehanicheskih naturnyih ispyitaniy sistem osteosinteza s uchetom tsiklicheskih nagruzok, Litopis travmatologiyi ta ortopediyi, no 1-2, (29-30), pp. 115-120. 